\section{Original Article}

Check for updates

\title{
Understanding perspectives and lived experiences of at-risk Taiwanese teenage boys through photovoice
}

\author{
Victor Hsiao $\left(\mathbb{D},{ }^{\prime}\right.$ Sunya Chen $\mathbb{1}^{\circ},{ }^{2}$ Mellissa Withers $\mathbb{B}^{1}$ \\ 'Keck School of Medicine, University of Southern California, Los Angeles, CA, USA \\ ${ }^{2}$ Taiwan Out-of-Home Youth Placement Facility (unnamed for confidentiality)
}

Received: Oct 5, 2019

Accepted: Nov 13, 2019

Correspondence to

Victor Hsiao

Keck School of Medicine, University of Southern California, $2001 \mathrm{~N}$ Soto Street SSB 318G Los Angeles, CA 90089 USA.

E-mail: victor.hsiao@usc.edu

(c) 2019 Korean Society of Global Health. This is an Open Access article distributed under the terms of the Creative Commons Attribution Non-Commercial License (https:// creativecommons.org/licenses/by-nc/4.0/) which permits unrestricted non-commercial use, distribution, and reproduction in any medium, provided the original work is properly cited.

ORCID iDs

Victor Hsiao (D)

https://orcid.org/0000-0002-2409-6436 Sunya Chen (iD

https://orcid.org/0000-0002-3811-2038

Mellissa Withers (D)

https://orcid.org/0000-0001-7754-0206

Conflict of Interest

No potential conflict of interest relevant to this article was reported.

\section{Author Contributions}

Conceptualization: Hsiao V, Withers M; Data curation: Hsiao V, Chen S; Formal analysis: Hsiao V, Chen S, Withers M; Funding acquisition: Hsiao V; Investigation: Hsiao V, Chen S; Methodology: Hsiao V, Withers M; Project administration: Hsiao V, Chen S, Withers M; Resources: Hsiao V, Withers M;

\section{ABSTRACT}

Background: At-risk youth often have many unmet health needs and higher prevalence of negative health outcomes. This study fills a gap in the literature regarding the views of at-risk Taiwanese youth, especially those in foster care and the juvenile justice system by: 1) identifying common themes in at-risk boys' perspectives about their lived experiences and health needs, and 2) generating compelling evidence to better advocate for these youth by sharing their needs and experiences with stakeholders.

Methods: Photovoice is a qualitative research method in which participants produce photographs and narratives to communicate their perspectives. Thirteen youth from a Taiwan placement facility for teenage boys in foster care or the juvenile court system participated in this yearlong study. After receiving in-depth training, participants spent 3 months taking photos and writing accompanying narratives relating to the research questions. Then, via facilitated individual and group meetings, participants selected photo-narrative pairings they felt best described and captured their experiences in relation to the research questions. Key themes were identified. Photo-narrative pairings were exhibited for local stakeholders. Results: The identified themes were: the lack of and need for companionship, complex relationships with family, the fear of but also benefit of the law, the desire to belong in and be accepted by society, and the impact of activities as a means of stress relief and character development. Participants' conceptualization of health needs primarily centered around psychological stress relating to these themes. Participants perceived sustained mentorship and self-esteem building activities as critical to building resilience and lasting behavioral changes. Conclusion: Youth's perspectives must be at the center of research to make the most wellinformed policy decisions. The results shed light on the lived experiences of at-risk youth and how these experiences relate to their health and wellness, and should be used to inform policy recommendations regarding resiliency- and health-promoting services.

Keywords: Adolescent health; Community-based participatory research; Juvenile delinquency; Foster care 
Supervision: Hsiao V, Withers M; Validation: Hsiao V, Withers M; Visualization: Hsiao V; Writing - original draft: Hsiao V; Writing review \& editing: Hsiao V, Chen S, Withers M.

\section{INTRODUCTION}

At-risk youth are defined as youth who are less likely to transition successfully into adulthood. ${ }^{1}$ Youth in the child welfare or juvenile court system may experience numerous unmet physical, developmental, and mental health needs. ${ }^{2,3}$ This is true in Taiwan where adverse childhood experiences (ACEs) and various forms of maltreatment are quite prevalent. Among Taiwanese youth, $91 \%$ have experienced some form of maltreatment in their lifetime with $83 \%$ experiencing maltreatment in the past year. ${ }^{4}$ One study found that the most common ACEs among Taiwanese youth were verbal abuse (37\%) and physical abuse (27\%), and that ACEs were associated with physical fights, property damage, running away from home, bullying victimization, and sleep problems. ${ }^{5}$ Limited studies describe possible causes and health issues associated with deviant behavior and delinquency among the Taiwanese adolescent population. Some studies have found that regular substance use, having peers who use substances, poor academic performance, and family conflicts are associated with drug use and school suspension among this population. ${ }^{6,7}$ Suppression of negative emotions such as anger and depression to maintain social harmony in Taiwan's collectivistic culture has been suggested to negatively impact Taiwanese youth's wellbeing and potentially lead to delinquency. ${ }^{8}$ In one Taiwanese study, $44.1 \%$ of incarcerated youth experienced psychological distress, of which $36.8 \%$ experienced sleep disturbance and $34.7 \%$ experienced depression; the psychological distress was correlated with female gender, poor self-rated health status, gang involvement, life disturbances prior to imprisonment, and smoking. ${ }^{9}$

To design successful interventions for at-risk youth, their perspectives must be both understood and included in the design of interventions. Most research in this area has been conducted in Western contexts, with limited discussion of the perspectives of at-risk youth in other global contexts. Furthermore, there is scant literature about Taiwanese youth in the foster care or juvenile justice system and their views towards their lived experiences and health needs. ${ }^{10}$ Using photovoice, this study aimed to address this gap in the literature by: 1 ) identifying common themes in at-risk boys' perspectives about their lived experiences and health needs, and 2) generating compelling evidence to better advocate for these youth by sharing their needs and experiences with stakeholders.

\section{METHODS}

\section{Photovoice}

Photovoice is a qualitative, participatory research method that allows individuals to produce photographs and narratives to communicate their priorities and experiences. ${ }^{11}$ In photovoice, participants take photos and write narratives relating to a research question. Then, through facilitated group discussions, photos are reviewed and sorted by common themes. Finally, the results are shared with community stakeholders through exhibitions of selected photos and accompanying narratives.

Photovoice gives participants an active role in producing and analyzing the data regarding a reality that is best known by them. It allows for the identification of community needs, as well as validation of the community's experiences, which is thought to lead to greater empowerment of traditionally marginalized groups. Photovoice has also been shown to empower participants in numerous ways, including the acquisition of knowledge and increased critical awareness of their community, improved ability to articulate their perspectives, positive 
changes in self-perception and self-efficacy, and development of wider social networks and connections with stakeholders. ${ }^{12}$ Photovoice, with the combination of photographs and narratives, further provides data with richness and details that may be less accessible with other qualitative methods, such as surveys or interviews, which rely on participants' verbal communication skills and can be perceived as impersonal, awkward, or even intimidating. ${ }^{13,14}$ Using photography can also be beneficial in helping participants convey their experiences and perspectives when they have decreased communication and literacy levels, as in the case of youth offenders. ${ }^{15,16}$ In selecting a research methodology, the research team strongly considered how each methodology would influence the dissemination of study findings. Photovoice was selected because the team believed that having the combination of both the photographs and narratives in photovoice would more greatly attract the interest of community members and stakeholders, thus aiding in the sharing of the research findings. Furthermore, the use of symbolism in photography often works well for sensitive topics because it can provide distance and a protective layer from a painful experience while also describing the experience in a way that is more meaningful than could be expressed by words alone. ${ }^{17,18}$ Photovoice has been used in research with underserved and/or marginalized communities worldwide on topics such as health among the homeless, human immunodeficiency virus (HIV)/acquired immunodeficiency syndrome (AIDS), depression and suicide, and grief. . $^{148-21}$ It has also been used among youth from different stigmatized backgrounds, including those who are receiving mental health services, living in high-risk neighborhoods, HIV-positive, and in foster care. ${ }^{22-27}$

\section{Setting}

This yearlong study was conducted in Taiwan at a Christian-based placement facility that offers support services to teenage boys in foster care or the juvenile court system. During the study, 26 boys received full-time daily residential care. Boys from the welfare system typically stay until age 18 , while those from the juvenile justice system typically stay for 2-4 years.

All boys at the facility during the study period were verbally invited to participate. Participant responsibilities (project activities and time commitment) and ethical concerns (stress or negative emotional responses, privacy, and confidentiality) were described in writing and verbally for each participant to consider before joining the study. Participants were notified that their photos and narratives would be shown in exhibitions but that they could withdraw their work at any time. Monthly suicidal ideation screenings were conducted to ensure participant safety. Pre-existing facility infrastructure included onsite psychological counseling and social workers. Informed consent forms in Mandarin Chinese were signed by participants and their legal guardians. Ethics approval was granted by National Taiwan University and the University of Southern California.

The onsite co-investigator was a medical student from the US who previously volunteered at the facility and had developed relationships with the staff and boys. He is ethnically Taiwanese-Cantonese-American and speaks Mandarin Chinese. The two female study facilitators were both full-time facility staff (guidance counselor and social worker) who had worked at the facility for more than 10 years. They were trained on the study design, group facilitation techniques, and ethics. Facilitator and participant trainings were adapted from existing photovoice manuals and one of the co-investigators' previous work. ${ }^{28,29}$

\section{Training and data collection}

This project focused on the participants' perceived health needs utilizing a strengths-based approach to highlight resilience, sources of support, and hope for the future, as opposed to 
focusing retrospectively on negative past experiences. The research questions guiding the project were "how do at-risk youth view their lived experiences", "how do these experiences relate to health and wellness?", and "what are their sources of strength and future hopes?" Training sessions of 1-2 hours were held weekly for two months. Participants received training on basic photography techniques, and ethics, including confidentiality and ethically portraying sensitive topics. ${ }^{30}$ Since much of the content was expected to be sensitive in nature, training emphasized the use of symbolism in photography.

During the 3-month data collection phase, participants took photos in response to different weekly prompts to encourage reflection and introspection relating to the research questions, such as self-perceived needs, future goals, sources of support, things they wish others knew about them, and ways society can better support them. When participants left the facility to take photos, a research team member accompanied them to mitigate situations that might put participants or photographed subjects at risk. Accompanying narratives were written for each photograph, describing each photograph's content and meaning. At the end of the photography period, participants chose their top 10 photo-narrative pairings based on those that they felt best captured their experiences in relation to the research questions. The narrative for each selected photo was then further revised and elaborated upon by the participants, in collaboration with the research team, in preparation for the analysis and dissemination stages of the study. These selected pairings were then discussed in group meetings during the study's data analysis phase. Each pairing was considered individually to incur minimal risk of harm to photographed or described subjects or those involved with the study, and any identifiable faces were blurred.

\section{Data analysis and dissemination}

In four group meetings, the co-investigator, facilitators, and participants together sorted the photo-narrative pairings and categorized them into three broad thematic groups: past, catalyst for change, and future. Through four additional group discussions, participants identified key themes and then chose 35 pairings which best related to these themes. Together, the participants wrote a collective statement for each theme expressing their shared experiences in relation to the given theme. At least six pairings were chosen for each theme and each participant had at least two pairings represented. To increase awareness of these youth's situations and create an impetus for policy changes to better support them, 13 presentations and three exhibitions with selected photos and narratives were held at local universities, hospitals, and government institutions. Community out-of-home placement facility staff, youth in juvenile detention, school children and teachers, volunteers, healthcare professionals, and social workers were invited to attend. Short presentations about the project were made by the onsite co-investigator at each exhibit, which explained the project's rationale, methodology, and findings. Written resource guides were also disseminated to attendees with tips for local volunteer opportunities, suggestions for working with youth, and a list of local placement facilities. Participants did not attend due to confidentiality issues but were briefed on the events and audience feedback. The work was also featured by local media in the newspaper and on television.

\section{RESULTS}

Thirteen boys completed the study (Table 1), 7 were high school students and 6 were middle school students. Seven were from the foster system and 6 from the court system. Six were from indigenous backgrounds. Despite the instructions to reflect on and write about all 
Table 1. Brief introduction to study participants. Pseudonyms are used.

\begin{tabular}{|c|c|c|}
\hline Name & Age (yr) & Description \\
\hline Ace & 16 & $\begin{array}{l}\text { Came to the facility due to his family's poor financial situation and whose father and } \\
\text { mother have now both passed away due to a car accident and alcohol use respectively. }\end{array}$ \\
\hline Alex & 14 & Came to the facility through the court system. \\
\hline Ben & 13 & Entered the court system due to theft. \\
\hline $\mathrm{Ed}$ & 17 & Often got into trouble at school and later came to the facility. \\
\hline Jacob & 15 & $\begin{array}{l}\text { Entered the foster care system due to his father's passing and his mother not being able } \\
\text { to care for him and sister. }\end{array}$ \\
\hline Jeremy & 15 & $\begin{array}{l}\text { Grew up in a dysfunctional family with inappropriate disciplinary styles and later } \\
\text { entered the court system due to theft. }\end{array}$ \\
\hline Joseph & 17 & Entered the court system due to theft. \\
\hline Kenny & 14 & Grew up with an abusive father and came to the facility after running away from home. \\
\hline Stephen & 15 & $\begin{array}{l}\text { Entered the system after being abandoned and came to the facility after being } \\
\text { transferred between different foster homes and facilities. }\end{array}$ \\
\hline TikTok & 18 & Entered foster care with his brother Ace (see above for description). \\
\hline Tony & 15 & Born in jail and came to the facility due to drug use. \\
\hline Tyler & 19 & Came to the facility after his father went to jail. \\
\hline Will & 15 & Came to the facility due to domestic abuse at home. \\
\hline
\end{tabular}

Descriptions were written based on study participants' preferences regarding disclosure of their backgrounds.

aspects of their lives, most photos and narratives centered on the past, with a much smaller percentage on their current lives, and even less about their futures. The 5 most salient themes that were chosen by the participants to reflect their individual and collective experiences were: 1) lack of and need for companionship, 2) complex relationships with family, 3) fear of but also benefit of the law, 4) desire to belong in and be accepted by society, and 5) activities as a means of stress relief and character development. The themes, with statements written collectively by the participants as well as examples of their photos and narratives, are presented below. Pseudonyms are used.

\section{Theme 1: Lack of and need for companionship}

"The lack of companionship is harmful to one's psychological health: without companionship, when we are under stress, we do not know how to handle it, and it can get us into trouble. Eventually, the darkness can become all-consuming, and we begin to feel completely alone. Yet even after leaving our families to be placed, we still miss our families, and we'll still feel nostalgic about the few good times we had with them.

After experiencing the companionship of many different people, we've changed quite a bit. Since someone is helping us, we know we can't give up on ourselves-because someone is rooting for us. As people walk with us through life, we learn to cherish this time that we have together, because their companionship can help us to learn many things that we didn't know before, whether it be new knowledge or a new attitude."

All the participants grew up in difficult environments that included poverty, drug use, abusive and/or incarceration of family members, and absent parental figures. The lack of positive parental models reduced opportunities to develop effective communication skills, positive relationships, or healthy coping mechanisms. The absence of these skills and relationships led to feelings of low self-esteem or self-worth, isolation, estrangement, and difficulty integrating into society (Fig. 1). Ace shared, "In the past I was always on my own and felt very lonely. There was no one to play with me so I just played on my own. Often times I would go out in nature or take a stick to go out and explore the world around me." Participants described the lack of companionship as being harmful to their psychological health. Tony explained, "Eventually, the darkness can become all-consuming, and we begin to feel completely alone." Without companionship 


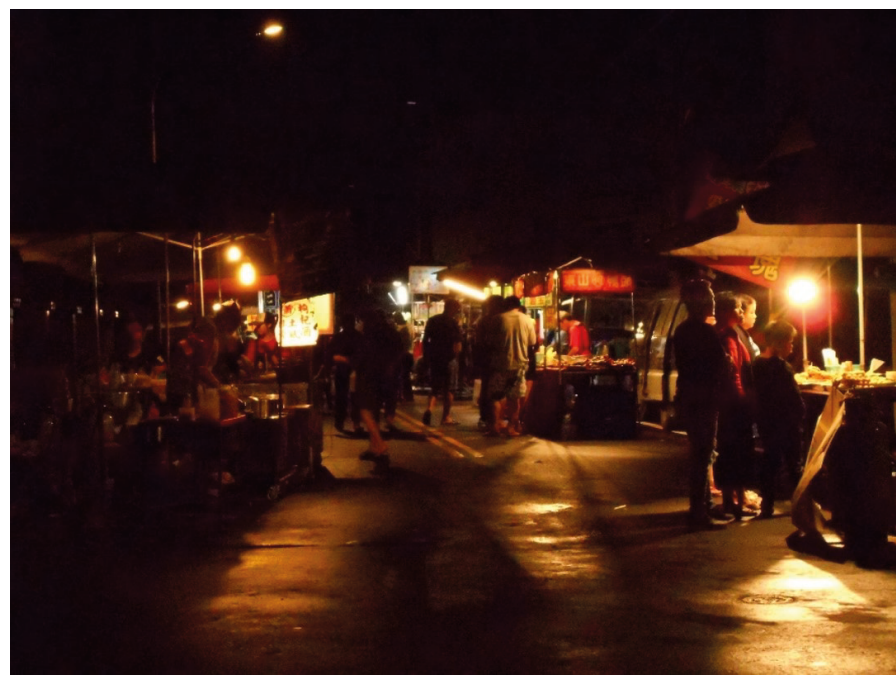

Fig. 1. Longing for Warmth. "In busy places, there is a certain sense of warmth and comfort. Another place that has this kind of warmth is the home. But my home does not have this kind of warmth. I don't know if it's because I can't feel the warmth, or if it's because it doesn't exist...you really want to wake up from this nightmare." - Kenny

and social support, participants experienced loneliness, which increased stress and often led them to get into trouble (Fig. 2).

Most participants also described the positive impact that companionship had on their lives, most often naming coaches. Tyler wrote, regarding his middle school basketball coach, "He helped me learn to courageously face every situation. At that time, I had very low-esteem and no selfconfidence, and was always alone... While I was on the basketball team, I learned how to interact with others, and I learned to improve myself through the lessons learned from my failures." Similarly, Joseph described a time when his elementary school track and field coach bought him socks that his family could not afford- "He ended up buying me socks, encouraging me, and helping me to not be so afraid of people. And slowly I walked out of that dark world and began interacting with others."

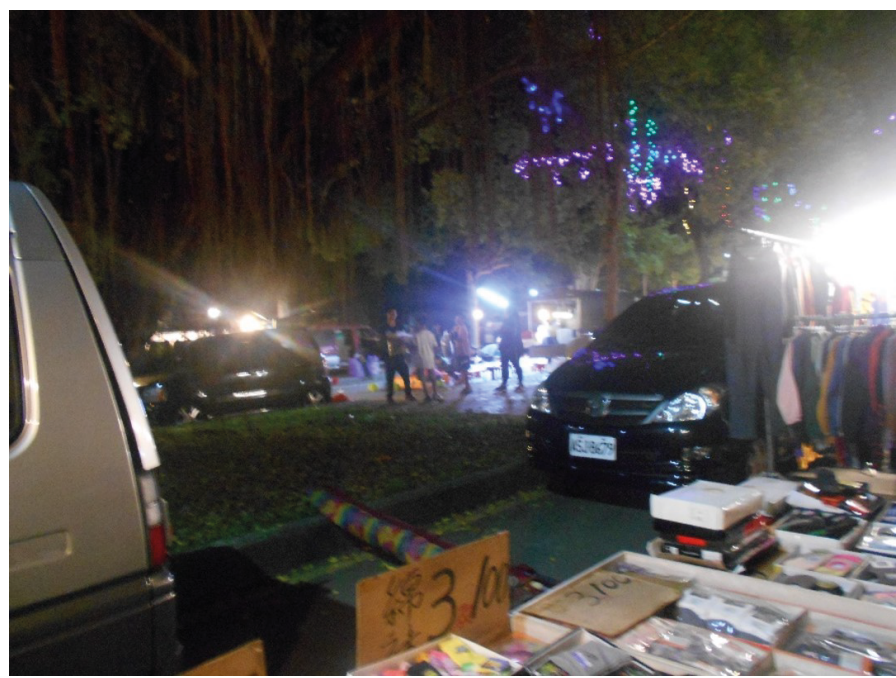

Fig. 2. Help. "In Taipei there are a lot of kids who meet up at night and get into trouble together. I think these kids simply lack people who care for them, people who can give them opportunities to utilize their talents. If our society just put a little more heart into it, it could help these kids." - Jeremy 


\section{Theme 2: Complex relationships with family}

"Most of us come from broken families. Maybe it was because our families were poor that when we were little we were malnourished and couldn't grow tall or gain enough weight. We didn't have anyone to support us when we were children, so it was very difficult for us to have any faith in the future once we entered school or society and had to interact with other people. We were afraid and didn't really trust anyone.

Even though our family circumstances were difficult, we still miss our families. Many people might not expect us to miss them, or they might say that Mom and Dad didn't do a very good job, but we still know that it was they who gave birth to us, raised us, and took care of us. We still miss them. Some of us might simultaneously miss them, hate them, and fear them-but in the end, they are still family."

All the participants came from broken families and most had mixed feelings about their home lives, often describing regular abuse, poverty, and hunger. For example, Joseph related growing up being very thin and stealing as a result of hunger (Fig. 3). Discussions also centered around how the limited support they had in childhood led to decreased hope for their future, mistrust towards others, and fear when interacting with others (Fig. 4). Due to the complexity of their family relationships even after they entered the system, the vast majority reported that their families continued to be sources of anxiety and stress. Despite this, all participants reported that they missed at least one member of their families. They often longed for love and acceptance and the opportunity to mend these relationships in the future. For example, Jeremy explained, "Saying that I didn't miss [home] would be a lie. I definitely miss it. But I also remember the emotional stress... so I'm very happy to be staying at the facility... some of us might simultaneously miss them, hate them, and fear them - but in the end, they are still family." Regarding some of his friends, TikTok wrote, "I was a little surprised that they were all so willing to be friends with me... [They] have good families, so I'm a bit envious of them. My family is not so good. My dad used to get drunk and fight with my mom every day. Sometimes they were so loud that the police would come. My dad would also beat us."

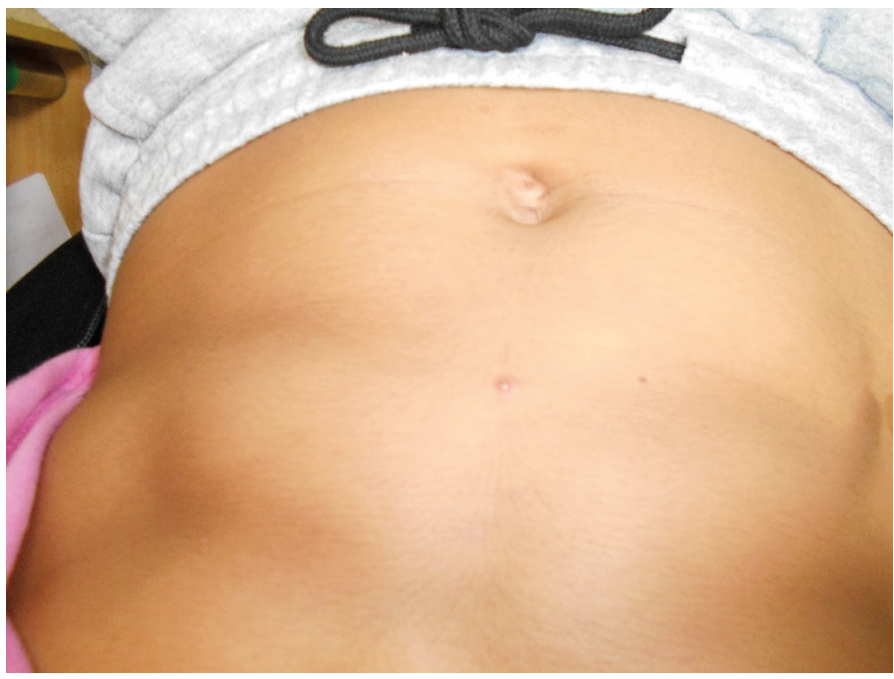

Fig. 3. A Strong Body Makes Me Better. "I used to be just skin and bones. I was never full from my meals each day... when I didn't have things to eat, all I knew to do was steal. But even then, I was rarely full because I could only get a little bit at a time. When I came to the facility, my appetite grew tremendously, so much so that the teachers here have joked that they're afraid I'll eat the facility into bankruptcy! ... I not only became stronger but also was able to eat much more." - Joseph 


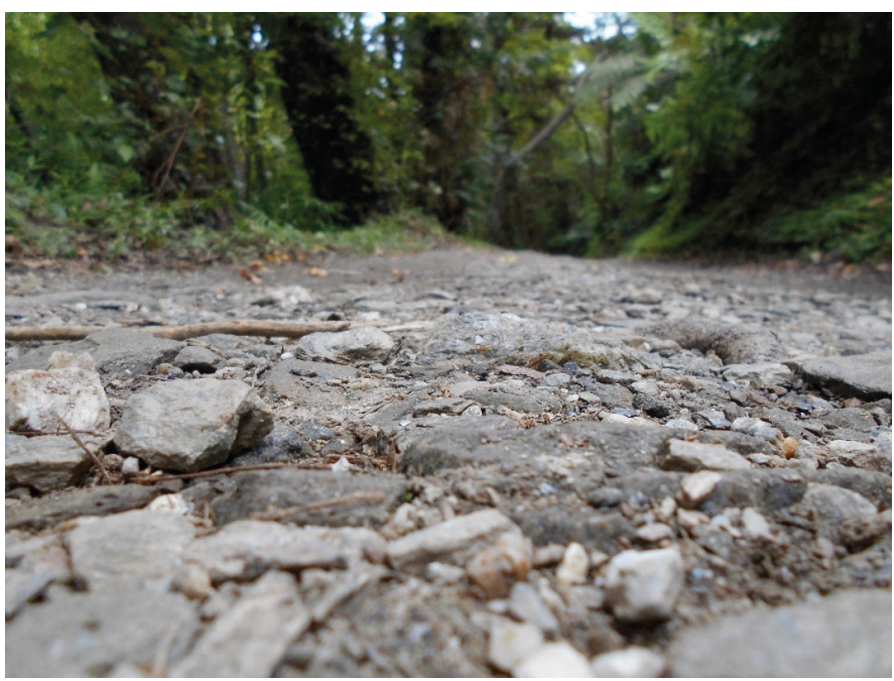

Fig. 4. Stress. "My life is like this photo - full of brokenness. I grew up in a dysfunctional family...My current struggle is with the stress of my continued education and life after the facility. I don't know what to major in, everyday life is financially stressful, and I worry about the unfamiliarity that will come with leaving the facility. These are all obstacles I'm trying my best to overcome.” - Tyler

\section{Theme 3: Fear of but also benefit of the law}

"Many of us didn't follow rules in the past, but we all had our reasons. They probably aren't the reasons that you'd first think of. Because of our behavior, we were all punished by the law. In juvenile hall, we had no dignity or freedom, leaving us feeling helpless, counting each day, and not knowing where we'd go next. We just wanted to get out, but getting out wasn't necessarily the best option because after getting out we'd still return to our previous lives. However, because of the law, we developed a sort of fear of punishment, so we would learn some self-control either while we were in juvenile hall, or after we got out. Otherwise, we used to not think about the consequences of our crimes. Often times, we would not only hurt ourselves, but those around us as well, and it would be exhausting trying to run from the law. After leaving juvenile hall, you are more cautious, avoiding actions that will hurt yourself. Honestly, following the rules makes life calmer and more stable."

While participants who had been involved in criminal activity acknowledged that it was wrong, they reflected on the reasons for their actions, such as joining a gang to protect friends from being bullied, stealing food due to hunger, and riding motorcycles at high speeds without a license to relieve stress (Fig. 5). They generally characterized their experiences in juvenile detention as negative due to a lack of dignity, decreased freedom, and feelings of helplessness. However, juvenile detention and the law provided stability, a sense of calm, and motivation to change, often for the first time in their lives (Fig. 6). Some mentioned counting each day until they were released even though they did not know where they would go. They also recognized that release was not necessarily the best option for them at this point because of the high likelihood of returning to criminal activity. Furthermore, the threat of returning to juvenile detention served to encourage positive behavioral changes and developing better coping skills. 


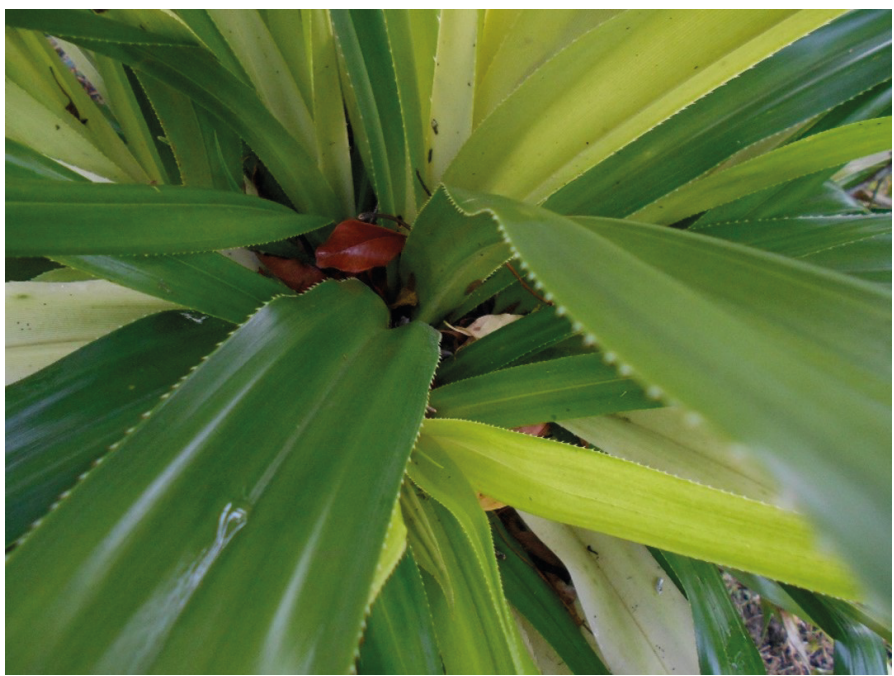

Fig. 5. A Prickly Me. "I used to be a very obedient and good boy. But one time, one of my good younger friends was bullied. I wanted to protect him, so I learned to be mean. I hung out with some of the older kids at school and would go home late all the time; I even started doing bad things with them. At the time, I thought I was becoming more powerful and that everyone was afraid of me. What I didn't realize was that by becoming a bad boy, I had made myself into the black sheep of the family, which led to the neighbors often making fun of my family. I thought about getting revenge. Whenever I saw those people who said bad things about my family, I'd glare at them, hoping that they would disappear from this world. If I talked to them, I'd do it with a very bad attitude, which would only make them dislike me even more. As such, I was very hard to get along with when I was a kid." - Joseph

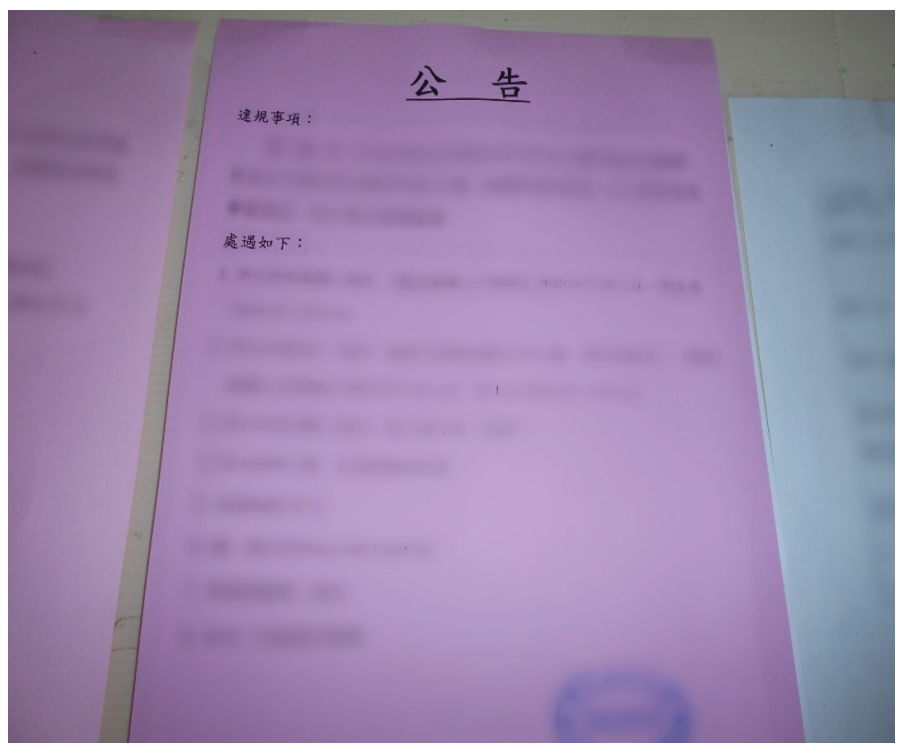

Fig. 6. Source of Support. "This disciplinary slip, a slip that is posted and has the boy's infraction as well as the disciplinary action he will receive,] is my support, a motivation for me to change. When I see this slip, I think of my family and case manager and how I don't want to let them down or be sent to a correctional facility." - Alex

\section{Theme 4: Desire to belong in and be accepted by society}

"When we first went to school after arriving at the facility, classmates who didn't know us would judge us based on stereotypes. Teachers wouldn't admit it, but they likely thought of us that way too. Others probably labeled us as well. It feels like most people only pity us or judge us for our pasts, instead of seeing us for who we are now. We feel sad after realizing this, but we do our best 
to accept it. We all hope that people will understand us more, accept us more, tolerate us more, and give us more chances. We hope that they will see that we're not the way they imagine us to be."

Participants often discussed the many negative ways that society viewed or interacted with them, which they felt affected their health negatively. They often felt stereotyped by teachers and classmates and that others judged them based on their pasts. Several acknowledged that they had tough external personas but reported that this did not reflect who they truly were inside (Fig. 7). For example, TikTok explained, "Although I look very mean on the outside, but I have a very gentle personality." Universally they mentioned the desire to be seen for more than their past mistakes or misfortunes (Fig. 8). They hoped for new identities that centered around

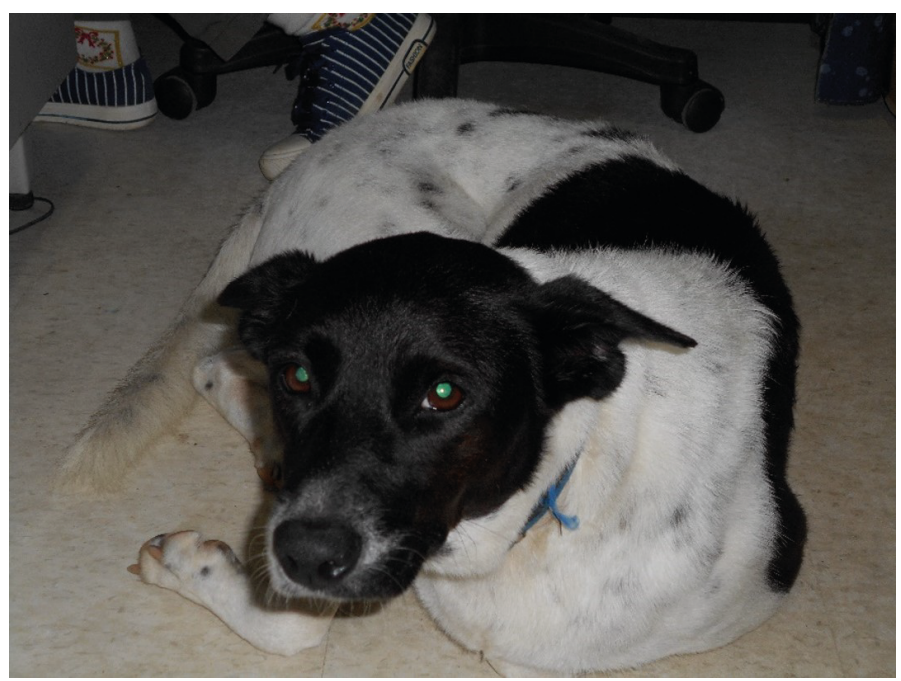

Fig. 7. My Weak Self. "This photo represents my weakness. In others' eyes I might seem strong, but actually I'm not. I'm just like this dog, shrinking myself tightly into the confines of my own world." - Kenny

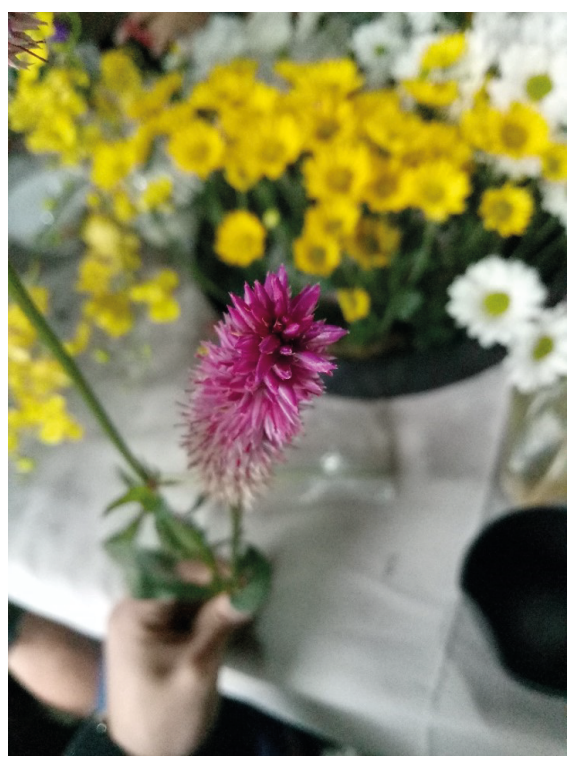

Fig. 8. Seeing Their Strengths. "I think people all have their good and bad sides. I always hope that others will only see my strengths, but in reality, people tend to look at others' shortcomings. It's like this flower: when people first look at it, they won't think it's that pretty. But it actually smells very good, and if you take a closer look, it also looks pretty good. Hopefully all aspects of me can be known and seen by people." - Ed 
who they are now, especially their strengths. For example, Kenny said, "In the past I wanted to work to change myself, but I failed. I hope there will be someone who won't give up on me."

\section{Theme 5: Activities as a means of stress relief and character development}

"Maybe compared to the average teenager, our experiences seem more unique. However, we also didn't have the chance to experience many of the things regular teenagers experience. The things we do get to experience here, whether it's hobbies, faith, or events, allow us to feel many feelings, such as comfort, happiness, self-confidence, and a sense of accomplishment. We can learn to speak gently and quietly, instead of threatening others; we learn practical skills, in order to find work in the future. Participating in these activities also allows us to experience a different kind of environment-a clean environment to live in, without gambling or swearing, one that gives us a sense of security, not being threatened or beat by our parents every day, and maybe making us feel that there is a higher power above, protecting us."

Participants often reflected positively on activities that they had participated in, many of which for the first time after coming to the facility, such as going to church, playing on the school basketball team, baking, going on nature hikes, learning to fix computers, visiting the beach, and swinging in the park. These activities provided stress relief, self-esteem, confidence, perseverance, and a sense of accomplishment that led to increased mental and emotional stability and readiness to face challenges (Fig. 9). Involvement in these activities promoted positive feelings, including self-confidence, perseverance, and a sense of accomplishment. All participants discussed how these activities allowed them to experience a healthy, stable environment, which gave them comfort and happiness. For example, Tyler described how a summer unicycle trip helped him develop perseverance and a strong work ethic (Fig. 10). Stephen wrote, "I live in the world of Tea King [a popular tea brand in Taiwan]... It has a sweet aftertaste. I don't mind its bitterness. It's like my life. Although I had a bitter beginning but if I set my life goals of becoming a computer engineer, my life will have a sweet aftertaste." A few participants also mentioned how faith in God, first introduced to them at the facility, positively impacted their lives. They described God as a source of support "who will always be with me", to "triumph over my mistakes", and to listen to "what's on my heart, and let him comfort me."

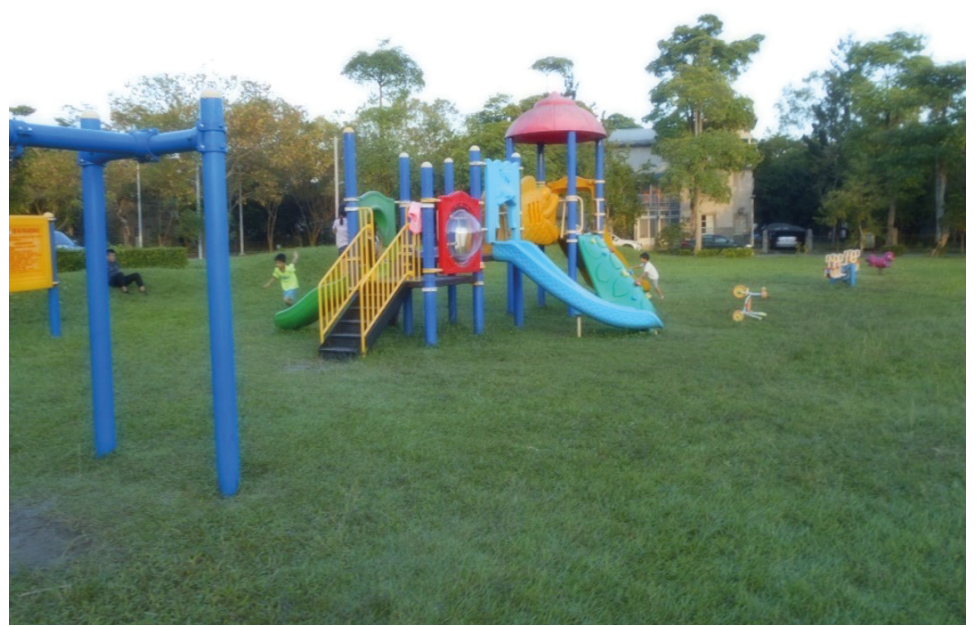

Fig. 9. Childhood. "Swinging is my favorite way to relax because you can swing from a really low point up to a really high point and then back down from high to low. It helps me forget my troubles." - Will 


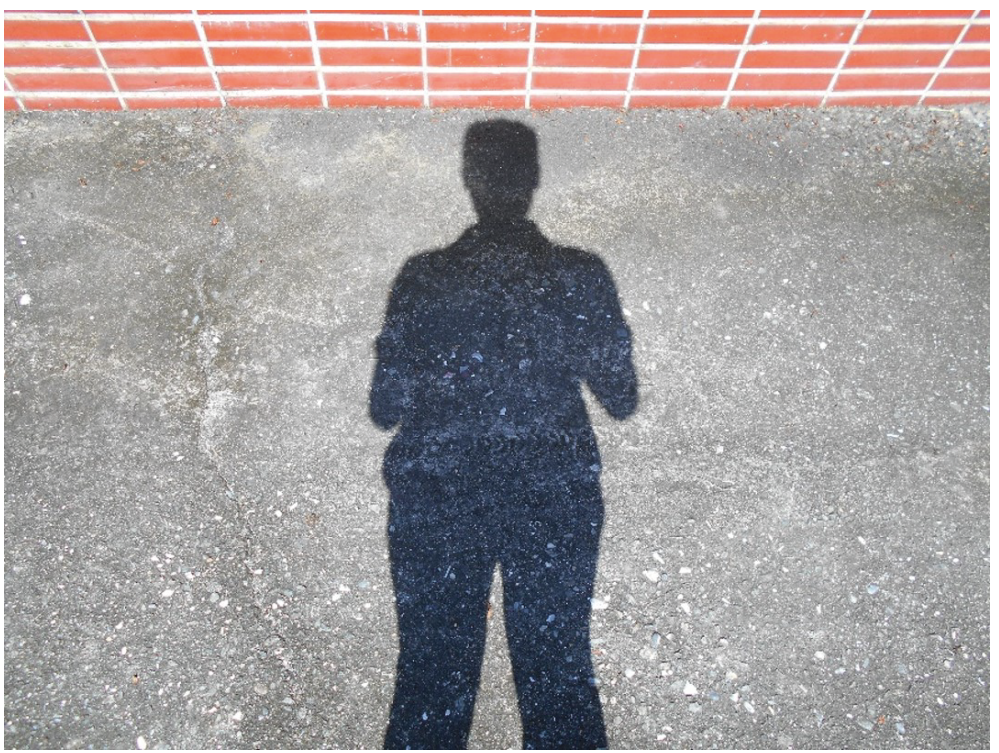

Fig. 10. Never Give Up! "I am a person with very little self-confidence. I'm always afraid of making mistakes and I'm afraid of facing crowds. Right now, the best kind of help for me is continuous encouragement as I search for a way to succeed! This summer, I achieved a small success in my life. I unicycled around the whole island of Taiwan with the facility. Even though it was very tiring, through the trip I learned how to work hard and persevere. Whenever I wanted to give up, I would tell myself that I hadn't reached the end yet. Never give up!" - Tyler

\section{DISCUSSION}

Greater awareness of how at-risk youth's lived experiences influence their decision-making processes and life trajectories is needed. Research can create an impetus for policy changes that benefit these youth; however, such research must keep their voices and perspectives at the center. The results of this participatory study shed light on how to support at-risk teenage boys to overcome their ACEs and lead happier, healthier lives. The youth were strong, resilient individuals and throughout the study, the researchers took a strengthsbased approach, hoping to highlight these positive qualities as well as the areas of the boys' lives that favorably influenced their development. However, the researchers privileged the subjective meaning of this study to the participants. As such, even though the hope was to focus primarily on these youth's strengths and the positive aspects of their lived experiences, the team allowed the participants to guide the overall findings of the study to ensure the results were credible and accurately represented these youth's views and perspectives. The results and analyses showed that many of their perspectives centered less on their strengths, and more on how their lives were influenced by those around them and other external factors. The study revealed that the participants' conceptualization of health needs primarily centered around psychological stress from various factors, such as lack of companionship, complicated family situations, low self-image, social isolation, and lack of opportunities for stress relief. These findings, although potentially reinforcing negative stereotypes of these youth, may highlight an important concept that many of these stereotypes and ideas have been internalized by these youth. The highly inter-related nature of these themes in the lives of these youth highlights the complexity and multi-dimensionality of working with this population. This study reveals some ways to deconstruct these beliefs and empower these youth, positively influencing their self-image, thought processes, actions, and ability to make change following their decisions. However, it will be worthwhile in future studies to continue exploring additional ways to support at-risk youth in these ways. The findings of this study 
also highlight the uniqueness of this population as the primary findings differ from a study about Taiwanese adolescents in general, which found that their concerns centered primarily around dietary health, body image, and academic stress. ${ }^{31}$

The first 2 themes relating to lacking companionship and complex family relationships showed that isolation, loneliness, and the lack of positive parental models were major barriers to developing effective communication skills, positive relationships, or healthy coping mechanisms, and instead led to increased stress. Participants highlighted the need for companionship and described loneliness and a lack of belonging as key factors in their early lives. These results align with another Taiwanese study showing a link between family dysfunction and decreased self-esteem, which in turn increased social anxiety. ${ }^{32}$ One study examining the perspectives of American incarcerated youth found that when home or school failed to meet youth's needs for love, attention, discipline and role models, they spent more time on the streets, which often led to criminal behavior and incarceration. ${ }^{33}$

Family support has been shown to buffer the negative relationship between stress and physical health among male college students ${ }^{34}$ but in the context of complex, damaged family relationships, it is understandable that participants described impactful relationships with non-family members, especially those relationships that were long-term, regular, and supportive. ${ }^{35,36}$ School teachers, physicians, coaches, police officers, social workers, and other adults who regularly interact with youth can, by being mentors and advocates, guide at-risk youth to make health-promoting decisions and better understand and manage their stress. Much literature regarding youth behavior has been conducted regarding the protective nature of family connectedness and increased communication within the family. ${ }^{37,38}$ However, youth living in foster care or the juvenile justice system may not be able to spend time with family members. As such, it may also be valuable to focus on other protective factors against psychological stress and risky behaviors which have been identified in the literature: healthy peer relationships, internal resilience, school connectedness, and increased self-concept..$^{39-41}$ Additional training could be provided to school staff to better equip them with skills to help youth develop resiliency and social connections. This type of training might be especially beneficial in the Taiwanese context where, compared to in Western contexts, adolescents tend to spend longer hours in school and turn to teachers more often for advice regarding sexual and mental health needs. ${ }^{31}$ In a culture where academic success is highly valued and emphasized, attention should be given to making school a welcoming environment for these youth who traditionally have had lower academic performances. It would also be worthwhile to further explore whether the importance of family members and mentors is magnified in the lives of Taiwanese youth, compared to their Western counterparts, given local cultural emphases on the family unit and familial ties.

Another theme that featured prominently was that although engagement in the juvenile justice system was a negative experience, it had positive impacts on participants' mental health in creating calm and stability. These findings are similar to those described by American youth in the juvenile justice system, who highlighted the painfulness of being separated from family and restrictions on freedom, but also discussed the safety and structure it provided in the context of their chaotic lives. ${ }^{33}$ The youth were very aware of the problems with their delinquent behavior but explained reasons for their decisions that stemmed from life stressors, such as lack of food and friends being bullied. ${ }^{33,42}$ They elaborated that being removed from unhealthy environments can be a temporary solution. These findings suggest a need for initiatives that do not solely focus on educating youth about 
the problems with their behavior but are aimed at addressing systemic stressors at the familyor societal-level. Ongoing neglect has been shown to significantly increase the likelihood of continued offending likely due to the role of parental monitoring and family relationships in influencing youth behavior. ${ }^{43}$ Among male adolescents, neglect victimization has been correlated with general recidivism whereas physical abuse victimization has been linked to violent recidivism. ${ }^{44}$ Regarding the influence of Taiwan's societal structure, the national high school entrance exam has been linked to increased deviant behavior and also indirect effects relating to delinquent peers and low school attachment. ${ }^{45}$ Decreased socioeconomic position was also associated with increased mental illness symptoms, infections, injuries, allergies and dental problems among adolescents in Taiwan ${ }^{46}$ Further exploration is needed regarding youth perceptions of juvenile detention on their lives, both while in and following detention. This research would increase understanding about the extent to which positive change in these youth's lives result from juvenile detention, reductions in environmental stressors, mentorship, or other factors.

Stressed adolescents have also been shown to be more likely to engage in risky behaviors, with decreased sensitivity to the costs and increased sensitivity to the rewards of potential decisions. ${ }^{47,48}$ In the US, youth have benefited from prevention programs aimed at diverting juvenile offenders from entering the juvenile justice system and encouraging community reintegration. ${ }^{49}$ More work in this area remains to be done in Taiwan.

Life stressors often manifested themselves not only as delinquent behavior but also as psychological stress stemming from wanting to be seen for more than their past mistakes or misfortunes as well as hoping to feel accepted and belonging in society. Although this sentiment is nearly universal among youth, those from this population often lack the social support systems and resources to buffer these stressors and decrease the likelihood of engagement in delinquent behavior. In the words of Jeremy, "I think these kids simply lack people who care for them, people who can give them opportunities to utilize their talents. If our society just put a little more heart into it, it could help these kids." The youth described feeling judged and labeled, and wanting to be further understood, accepted, tolerated, given more chances, and to be seen for who they are now. In response to devaluation and uncertainty in foster care, youth in foster care also use numerous self-protection techniques, including hiding foster care status and maintaining distance and superficiality in relationships with those not in the system, which resulted in increased self-reliance but also social detachment. ${ }^{50,51}$ As found in this study, this negative cycle often leads to unhealthy coping mechanisms and decreased self-esteem; the latter has been associated with decreased mental and physical health, worse economic prospects, and increased criminal behavior during adulthood. ${ }^{52}$ No studies have been published describing the stigma perceived by youth in the foster care or juvenile justice system in Taiwan or many other Asian contexts. There was also no literature found relating the perceptions of youth in the juvenile justice system regarding how their time in the system was viewed by themselves and those around them during and following leaving the system. This lack of literature describing these youth's experiences is not unexpected given their protected status while in the system and the challenges of getting in contact with them after they leave. However, understanding their perspectives cannot be understated in the effort to address their physical and mental health needs.

Growing up in impoverished homes, many of the youth lacked financial resources to participate in activities that help them to build positive relationships and develop self-esteem outside of the home. The study's results showed that the activities that best prompted long- 
term personal growth and character development were generally more difficult and required greater accountability to master, such as unicycling around the island of Taiwan, playing on the basketball team, and developing computer repair skills. Required parental involvement, financial costs, regular disruptions in their lives due to bad behavior and consequential disciplinary or legal actions, or simply the instability of their lives were barriers to previous participation. Even short-term activities, such as baking, exercising, and swinging in the park, provided participants with the opportunity to find new interests and relieve stress by shifting their attention to the activity at hand. Physical activity has not been shown to reduce juvenile delinquency. ${ }^{53}$ Possibly it is not the activity itself that supports these youth and aids transition into adulthood, but rather skills such as independence, self-direction, and goalsetting, learned from the activity. ${ }^{54,55}$ These findings suggest that at-risk youth should be offered more activities that encourage the development of coping skills, interpersonal skills, and/or self-esteem. Often in schools and placement facilities, youth with deviant behaviors are required to stabilize their behavior before they can participate in extracurricular activities. However, these activities should be encouraged because they may be the catalyst for some youth to make changes in their lives and continue to improve. Numerous participants in this study noted that participating in this photovoice project, meeting with other youth from similar backgrounds, and articulating their stories and needs was empowering for them. ${ }^{27,56,57}$ Similarly, interventions encouraging development of cognitive skills have been shown to reduce stress among adolescents but there is also a need for strengthening of external resources such as family support and community resources. ${ }^{58}$

Participants' comments about the importance of faith align with research that demonstrates that religion and religious affiliation have been associated with improvements in physical health outcomes, mental health outcomes, healthy behaviors, and coping among adolescents and in the general population. ${ }^{59-61}$ Among Taiwanese adults, belief that there is meaning to life was negatively associated with anxiety and partially mediated the relationship between anxiety and mental health. ${ }^{62}$ The role of religion, in this case the Christian faith, should be further explored as a potential source of support and protective factor for at-risk youth.

At-risk youth in the foster care or juvenile justice system often have stress that results from a variety of social factors but they also frequently lack the support systems to buffer against this stress and teach them healthy coping mechanisms. As described previously, having longterm, positive role models and mentors can be extremely beneficial. Given the trauma that many of these youth have experienced, trauma-informed care is essential and can improve their quality of life. ${ }^{63,64}$ It is critical that these youth have access to mental health services provided by individuals with experience and training in working with adolescents, especially those with at-risk backgrounds. In Taiwan, less than $5 \%$ of adolescents use healthcare services for mental and emotional needs. ${ }^{31}$ Unfortunately, this low usage may not be due to lack of resources but psychological, social, structural and cultural barriers, including issues of familiarity with the services, stigma, and confidentiality. ${ }^{65-67}$

Regarding limitations of this study, all participants were from one Christian-based facility. Therefore, the results may not accurately depict the experiences of boys in other contexts. The small sample size of 13 helped to ensure data quality but may limit external validity. Furthermore, the study team facilitated the individual and group meetings and therefore played a role in guiding decisions and thought processes. However, the boys' perspectives were prioritized, and they ultimately chose the themes, photos, and narratives included in the results. 
In conclusion, the photovoice methodology helped shed light on the lived experiences of at-risk youth and how these experiences relate to health and wellness. This study highlights the need for opportunities through which at-risk youth can develop their own strength and resiliency. These youth must gain the skills required to face their lives' unique challenges and steer their futures in the ways they hope for. The results suggest that policies to address systemic stressors as well as increase school connectedness, mentorship, and growth-promoting activities can be instrumental in promoting resiliency and wellbeing among at-risk youth. Longitudinal support of these youth is also crucial and requires the sustained investment of adults from many spheres of these youth's lives. A strengths-based approach, combined with long-term mentorship and opportunities to develop confidence and self-efficacy, are recommended to build on the youth's assets and create lasting positive behavior change.

\section{ACKNOWLEDGMENTS}

We thank our community partners (especially Dr. Chang-Chuan Chan and Dr. Shu-Sen Chang from National Taiwan University, Dr. Chaucer C.H. Lin and Shu Mei Chuang from Hualien Tzu Chi Hospital, and Hsiao-Chu Tseng from Taipei Veterans General Hospital Yuli Branch) for helping to organize the numerous presentations and exhibits. We also want to thank Victoria Su and Paul Yau for assisting with translation of the narratives. Furthermore, we would like to thank the Asia-Pacific Academic Consortium for Public Health Conference Committee for selecting the presentation of this work for the 2019 Best Oral Presentation Award in the Marginalized Populations Category. Lastly, thank you to the staff and boys at the placement facility for all your support throughout the duration of this study.

\section{REFERENCES}

1. Koball H, Dion R, Gothro A, Bardos M, Dworsky A, Lansing M, et al. Synthesis of Research and Resources to Support At-Risk Youth. Washington, D.C.: Office of Planning, Research and Evaluation, Administration for Children and Families, U.S. Department of Health and Human Services; 2011.

2. Ahrens KR, Garrison MM, Courtney ME. Health outcomes in young adults from foster care and economically diverse backgrounds. Pediatrics 2014;134(6):1067-74. PUBMED | CROSSREF

3. Coffey C, Veit F, Wolfe R, Cini E, Patton GC. Mortality in young offenders: retrospective cohort study. BMJ 2003;326(7398):1064. PUBMED | CROSSREF

4. Feng JY, Chang YT, Chang HY, Fetzer S, Wang JD. Prevalence of different forms of child maltreatment among Taiwanese adolescents: a population-based study. Child Abuse Negl 2015;42:10-9. PUBMED | CROSSREF

5. Wang YC, Moya Guerola M, Lin YC, Hsieh YP, Strong C, Tsai MC, et al. Effects of childhood adversity and resilience on Taiwanese youth health behaviors. Pediatr Neonatol 2019;60(4):368-76. PUBMED | CROSSREF

6. Yen CF, Hsu CC, Liu SC, Huang CF, Ko CH, Yen JY, et al. Relationships among mental health status, social context, and demographic characteristics in Taiwanese aboriginal adolescents: a structural equation model. Psychiatry Clin Neurosci 2006;60(5):575-83. PUBMED | CROSSREF

7. Kuo PH, Yang HJ, Soong WT, Chen WJ. Substance use among adolescents in Taiwan: associated personality traits, incompetence, and behavioral/emotional problems. Drug Alcohol Depend 2002;67(1):27-39. PUBMED | CROSSREF

8. Lin WH, Dembo R, Sellers CS, Cochran J, Mieczkowski T. Strain, negative emotions, and juvenile delinquency: the United States versus Taiwan. Int J Offender Ther Comp Criminol 2014;58(4):412-34. PUBMED | CROSSREF 
9. Lyu SY, Chi YC, Farabee D, Tsai LT, Lee MB, Lo FE, et al. Psychological distress in an incarcerated juvenile population. J Formos Med Assoc 2015;114(11):1076-81.

PUBMED | CROSSREF

10. Tsai MC, Lin SH, Chou YY, Lin SJ. Exploration of health status, healthcare utilization, and health service expectations among Taiwanese adolescents. Eur J Pediatr 2014;173(2):187-96.

PUBMED | CROSSREF

11. Wang C, Burris MA. Photovoice: concept, methodology, and use for participatory needs assessment. Health Educ Behav 1997;24(3):369-87. PUBMED | CROSSREF

12. Budig K, Diez J, Conde P, Sastre M, Hernán M, Franco M. Photovoice and empowerment: evaluating the transformative potential of a participatory action research project. BMC Public Health 2018;18(1):432. PUBMED | CROSSREF

13. Russinova Z, Wewiorski NJ, Cash D. Use of alternative health care practices by persons with serious mental illness: perceived benefits. Am J Public Health 2002;92(10):1600-3. PUBMED | CROSSREF

14. Oliffe JL, Bottorff JL. Further than the eye can see? Photo elicitation and research with men. Qual Health Res 2007;17(6):850-8. PUBMED | CROSSREF

15. Hopkins T, Clegg J, Stackhouse J. Young offenders' perspectives on their literacy and communication skills. Int J Lang Commun Disord 2016;51(1):95-109.

PUBMED | CROSSREF

16. Bryan K, Freer J, Furlong C. Language and communication difficulties in juvenile offenders. Int J Lang Commun Disord 2007;42(5):505-20.

PUBMED | CROSSREF

17. Kantrowitz-Gordon I, Vandermause R. Metaphors of distress. Qual Health Res 2016;26(8):1031-43. PUBMED | CROSSREF

18. Creighton G, Oliffe JL, Butterwick S, Saewyc E. After the death of a friend: young men's grief and masculine identities. Soc Sci Med 2013;84:35-43. PUBMED | CROSSREF

19. Bukowski K, Buetow S. Making the invisible visible: a Photovoice exploration of homeless women's health and lives in central Auckland. Soc Sci Med 2011;72(5):739-46. PUBMED | CROSSREF

20. Harley A. Picturing reality: power, ethics, and politics in using photovoice. Int J Qual Methods 2012;11(4):320-39. CROSSREF

21. Teti M, Murray C, Johnson L, Binson D. Photovoice as a community-based participatory research method among women living with HIV/AIDS: ethical opportunities and challenges. J Empir Res Hum Res Ethics 2012;7(4):34-43. PUBMED | CROSSREF

22. Vélez-Grau C. Using Photovoice to examine adolescents' experiences receiving mental health services in the United States. Health Promot Int 2018. DOI: 10.1093/heapro/day043. PUBMED | CROSSREF

23. Schuch JC, de Hernandez BU, Williams L, Smith HA, Sorensen J, Furuseth OJ, et al. Por Nuestros Ojos: understanding social determinants of health through the eyes of youth. Prog Community Health Partnersh 2014;8(2):197-205. PUBMED | CROSSREF

24. Acioli RM, Barreira AK, Lima ML, Assis SG, Lima ML. Foster care time and characteristics of adolescents under foster care by type of institutional services. Recife, Brazil, 2009-2013. Cien Saude Colet 2019;24(2):553-62. PUBMED | CROSSREF

25. Bashore L, Alexander GK, Jackson DL, Mauch P. Improving health in at-risk youth through photovoice.J Child Health Care 2017;21(4):463-75. PUBMED | CROSSREF

26. Adegoke CO, Steyn MG. A photo voice perspective on factors contributing to the resilience of HIV positive Yoruba adolescent girls in Nigeria. J Adolesc 2017;56:1-10. PUBMED | CROSSREF

27. Wilson N, Dasho S, Martin AC, Wallerstein N, Wang CC, Minkler M. Engaging young adolescents in social action through photovoice. JEarly Adolesc 2007;27(2):241-61. CROSSREF

28. Palibroda B, Krieg B, Murdock L, Havelock J. A Practical Guide to Photovoice: Sharing Pictures, Telling Stories and Changing Communities. Winnipeg: Prairie Women's Health Network; 2009. 
29. Blackman A. The Photovoice Manual: A Guide to Designing and Running Participatory Photography Projects. London: PhotoVoice; 2007.

30. Wang CC, Redwood-Jones YA. Photovoice ethics: perspectives from Flint Photovoice. Health Educ Behav 2001;28(5):560-72. PUBMED | CROSSREF

31. Tsai MC, Chou YY, Lin SJ, Lin SH. Factors associated with adolescents' perspectives on health needs and preference for health information sources in Taiwan. Arch Dis Child 2013;98(1):9-15. PUBMED | CROSSREF

32. Yen CF, Yang P, Wu YY, Cheng CP. The relation between family adversity and social anxiety among adolescents in Taiwan: effects of family function and self-esteem. J Nerv Ment Dis 2013;201(11):964-70. PUBMED | CROSSREF

33. Barnert ES, Perry R, Azzi VF, Shetgiri R, Ryan G, Dudovitz R, et al. Incarcerated youths' perspectives on protective factors and risk factors for juvenile offending: a qualitative analysis. Am J Public Health 2015;105(7):1365-71. PUBMED | CROSSREF

34. Lee CS, Dik BJ. Associations among stress, gender, sources of social support, and health in emerging adults. Stress Health 2017;33(4):378-88. PUBMED | CROSSREF

35. Van Dam L, Smit D, Wildschut B, Branje SJ, Rhodes JE, Assink M, et al. Does natural mentoring matter? A multilevel meta-analysis on the association between natural mentoring and youth outcomes. $A m J$ Community Psychol 2018;62(1-2):203-20. PUBMED | CROSSREF

36. Bellis MA, Hardcastle K, Ford K, Hughes K, Ashton K, Quigg Z, et al. Does continuous trusted adult support in childhood impart life-course resilience against adverse childhood experiences - a retrospective study on adult health-harming behaviours and mental well-being. BMC Psychiatry 2017;17(1):110. PUBMED | CROSSREF

37. Kapetanovic S, Skoog T, Bohlin M, Gerdner A. Aspects of the parent-adolescent relationship and associations with adolescent risk behaviors over time. J Fam Psychol 2019;33(1):1-11. PUBMED | CROSSREF

38. Shek DT, Zhu X. Paternal and maternal influence on delinquency among early adolescents in Hong Kong. Int J Environ Res Public Health 2019;16(8):E1338. PUBMED | CROSSREF

39. Hall-Lande JA, Eisenberg ME, Christenson SL, Neumark-Sztainer D. Social isolation, psychological health, and protective factors in adolescence. Adolescence 2007;42(166):265-86. PUBMED

40. Clements-Nolle K, Waddington R. Adverse childhood experiences and psychological distress in juvenile offenders: the protective influence of resilience and youth assets. J Adolesc Health 2019;64(1):49-55. PUBMED | CROSSREF

41. Levey EK, Garandeau CF, Meeus W, Branje S. The longitudinal role of self-concept clarity and best friend delinquency in adolescent delinquent behavior. J Youth Adolesc 2019;48(6):1068-81. PUBMED | CROSSREF

42. Erdelja S, Vokal P, Bolfan M, Erdelja SA, Begovac B, Begovac I. Delinquency in incarcerated male adolescents is associated with single parenthood, exposure to more violence at home and in the community, and poorer self-image. Croat Med J2013;54(5):460-8. PUBMED | CROSSREF

43. Ryan JP, Williams AB, Courtney ME. Adolescent neglect, juvenile delinquency and the risk of recidivism. $J$ Youth Adolesc 2013;42(3):454-65. PUBMED | CROSSREF

44. van der Put CE, de Ruiter C. Child maltreatment victimization by type in relation to criminal recidivism in juvenile offenders. BMC Psychiatry 2016;16(1):24. PUBMED | CROSSREF

45. Lin WH, Yi CC. Educational tracking and juvenile deviance in Taiwan: direct effect, indirect effect, or both. Int J Offender Ther Comp Criminol 2016;60(3):326-48. PUBMED | CROSSREF

46. Liang YL, Tsai MC, Lin YC, Strong C, Lin CY. Poverty and the prediction of health status in adolescents from low-income families in Taiwan. J Public Health (Oxf) 2019. DOI: 10.1093/pubmed/fdy220. PUBMED | CROSSREF

47. Jamieson JP, Mendes WB. Social stress facilitates risk in youths. J Exp Psychol Gen 2016;145(4):467-85. PUBMED | CROSSREF 
48. Cano-López I, Cano-López B, Hidalgo V, González-Bono E. Effects of acute stress on decision making under ambiguous and risky conditions in healthy young men. Span J Psychol 2016;19:E59. PUBMED | CROSSREF

49. Smokowski PR, Rose RA, Evans CB, Barbee J, Cotter KL, Bower M. The impact of teen court on rural adolescents: improved social relationships, psychological functioning, and school experiences. J Prim Prev 2017;38(4):447-64. PUBMED | CROSSREF

50. Kools S, Kools S. Self-protection in adolescents in foster care. J Child Adolesc Psychiatr Nurs 1999;12(4):139-52. PUBMED | CROSSREF

51. Rogers J. 'Different' and 'Devalued': managing the stigma of foster-care with the benefit of peer support. Br J Soc Work 2017;47(4):1078-93. CROSSREF

52. Trzesniewski KH, Donnellan MB, Moffitt TE, Robins RW, Poulton R, Caspi A. Low self-esteem during adolescence predicts poor health, criminal behavior, and limited economic prospects during adulthood. Dev Psychol 2006;42(2):381-90. PUBMED | CROSSREF

53. Faulkner GE, Adlaf EM, Irving HM, Allison KR, Dwyer JJ, Goodman J. The relationship between vigorous physical activity and juvenile delinquency: a mediating role for self-esteem? J Behav Med 2007;30(2):155-63. PUBMED | CROSSREF

54. Powers LE, Fullerton A, Schmidt J, Geenen S, Oberweiser-Kennedy M, Dohn J, et al. Perspectives of youth in foster care on essential ingredients for promoting self-determination and successful transition to adult life: My life model. Child Youth Serv Rev 2018;86:277-86.

PUBMED | CROSSREF

55. Carroll A, Gordon K, Haynes M, Houghton S. Goal setting and self-efficacy among delinquent, at-risk and not at-risk adolescents. J Youth Adolesc 2013;42(3):431-43. PUBMED | CROSSREF

56. Strack RW, Magill C, McDonagh K. Engaging youth through photovoice. Health Promot Pract 2004;5(1):49-58. PUBMED | CROSSREF

57. Wang CC. Youth participation in photovoice as a strategy for community change. J Community Pract 2006;14(1-2):147-61. CROSSREF

58. Rew L, Johnson K, Young C. A systematic review of interventions to reduce stress in adolescence. Issues Ment Health Nurs 2014;35(11):851-63. PUBMED | CROSSREF

59. Cotton S, Zebracki K, Rosenthal SL, Tsevat J, Drotar D. Religion/spirituality and adolescent health outcomes: a review. J Adolesc Health 2006;38(4):472-80. PUBMED | CROSSREF

60. Puchalski CM. The role of spirituality in health care. Proc Bayl Univ Med Cent 2001;14(4):352-7. PUBMED | CROSSREF

61. Chatters LM. Religion and health: public health research and practice. Annu Rev Public Health 2000;21(1):335-67. PUBMED | CROSSREF

62. Shiah YJ, Chang F, Chiang SK, Lin IM, Tam WC. Religion and health: anxiety, religiosity, meaning of life and mental health. J Relig Health 2015;54(1):35-45. PUBMED | CROSSREF

63. de Ruigh EL, Popma A, Twisk JW, Wiers RW, van der Baan HS, Vermeiren RR, et al. Predicting quality of life during and post detention in incarcerated juveniles. Qual Life Res 2019;28(7):1813-23. PUBMED | CROSSREF

64. Branson CE, Baetz CL, Horwitz SM, Hoagwood KE. Trauma-informed juvenile justice systems: a systematic review of definitions and core components. Psychol Trauma 2017;9(6):635-46. PUBMED | CROSSREF

65. Walsh J, Scaife V, Notley C, Dodsworth J, Schofield G. Perception of need and barriers to access: the mental health needs of young people attending a Youth Offending Team in the UK. Health Soc Care Community 2011;19(4):420-8. PUBMED | CROSSREF

66. Abram KM, Paskar LD, Washburn JJ, Teplin LA. Perceived barriers to mental health services among youths in detention. J Am Acad Child Adolesc Psychiatry 2008;47(3):301-8. PUBMED | CROSSREF

67. Anderson L, Vostanis P, Spencer N. Health needs of young offenders. J Child Health Care 2004;8(2):149-64. PUBMED | CROSSREF 